\title{
Update on Biologics in Treatment of Chronic Rhinosinusitis With Nasal Polyposis
}

\author{
Su-Jong Kim ${ }^{\mathbb{D}}$, Jee Won Moon, and Heung-Man Lee ${ }^{\mathbb{D}}$ \\ Department of Otorhinolaryngology-Head and Neck Surgery, Guro Hospital, Korea University College of Medicine, Seoul, Korea \\ 비용종을 동반한 만성 비부비동염 치료에서 생물학적 제제의 최신 지견 \\ 김수종 · 문지원 · 이흥만 \\ 고려대학교 의과대학 구로병원 이비인후-두경부외과학교실
}

\author{
Received August 2, 2021 \\ Revised September 3, 2021 \\ Accepted September 8, 2021 \\ Address for correspondence \\ Heung-Man Lee, MD, PhD \\ Department of Otorhinolaryngology- \\ Head and Neck Surgery, \\ Guro Hospital, \\ Korea University \\ College of Medicine, \\ 148 Gurodong-ro, Guro-gu, \\ Seoul 08308, Korea \\ Tel +82-2-2626-3185 \\ Fax +82-2-868-0475 \\ E-mail 1hman@korea.ac.kr
}

Chronic rhinosinusitis is a common chronic inflammatory condition of sinonasal cavities and occurs with or without nasal polyps. Uncontrolled chronic rhinosinusitis with nasal polyp (CRSwNP) has a negative impact on an individual's quality of life. Many studies have been conducted for novel treatments targeting type 2 cytokines involved in CRSwNP such as interleukin (IL)-4, IL-5, IL-13 and immunoglobulin E. Biologics have recently been proven to improve the nasal symptoms of CRSwNP and reduce the need for systemic glucocorticosteroids. Recently dupilumab, omalizumab and mepolizumab were approved by Food and Drug Administration for CRSwNP, and other biologics are under investigation. Large-scale and longterm clinical trials are needed for therapeutic effectiveness, and several questions remain regarding patient selection, treatment algorithm, and cost-effectiveness. Nevertheless, emerging biologics may offer a new therapeutic option for uncontrolled CRSwNP.

Korean J Otorhinolaryngol-Head Neck Surg 2021;64(10):693-702

Keywords Biologics; Cytokines; Nasal polyp; Sinusitis; Th2 cells.

\section{서 론}

만성 비부비동염은 비과 질환에서 흔한 염증성 질환으로 전 세계 성인의 5\%-12\%에 영향을 미치며, 우리나라에서도 유 병률이 전체 인구의 약 $8.4 \%$ 로 알려져 있다.1.2) 일반적으로 만 성 비부비동염은 표현형에 따라 비용종을 동반하는 만성 비 부비동염(chronic rhinosinusitis with nasal polyp, CRSwNP) 과 비용종을 동반하지 않는 만성 비부비동염(chronic rhinosinusitis without nasal polyp, CRSsNP)으로 분류한다. ${ }^{2)}$ 만성 비부비동염의 약 $80 \%$ 에서 비용종을 동반하지 않지만, 비용 종을 동반하는 만성 비부비동염에서는 임상증상이 심하고 치 료가 어렵다. ${ }^{3)}$ 수술과 약물 등의 고전적인 치료만으로 조절

This is an Open Access article distributed under the terms of the Creative Commons Attribution Non-Commercial License (https://creativecommons.org/licenses/by-nc/4.0) which permits unrestricted non-commercial use, distribution, and reproduction in any medium, provided the original work is properly cited.
되는 경우도 있지만, 부비동 내시경수술 후에 $16.2 \%$ 에서 비 용종이 재발하며, ${ }^{4)}$ 경구 스테로이드는 장기간 사용으로 인한 부작용 때문에 지속적으로 사용 가능하지 않다. 이처럼 조절 되지 않는 CRSwNP의 치료에서 발생하는 어려움 때문에 기 존의 치료 방법 외에 새로운 치료 방법을 개발하고자 하는 노 력이 계속되고 있다.

생물학적 제제는 생물체에서 유래한 물질이나 생물체를 이 용하여 생성한 물질을 함유한 의약품으로서 염증성 질환의 병태생리 내에서 특정 분자경로를 표적으로 한다. 지난 15년 간 생물학적 제제는 호산구성 천식이나 아토피 피부염, 만성 두드러기 등과 같은 만성 염증성 질환에서 승인되어 사용되 어 왔으며, 특히 항immunoglobulin E ( $\mathrm{IgE}$ ) 제제는 중증 천 식 환자의 1 차 요법으로 사용되고 있다.5) 천식을 동반한 비부 비동염 환자는 천식을 동반하지 않은 환자보다 비부비동염의 중증도 점수가 높고 비용종 발생률이 더 높으며, ${ }^{6,7)}$ 비용종과 
천식 사이의 강한 연관성으로 인하여 천식 환자에서 좋은 결 과를 보인 생물학적 제제가 천식을 동반한 CRSwNP 환자의 치료로 제시되었다. ${ }^{8}$ 이후 다양한 단일클론항체에 대하여 $\mathrm{CRSwNP}$ 의 치료 효과를 분석하는 연구가 진행되었고, 항 interleukin (IL) -4 receptor $\alpha$ 단일클론항체인 dupilumab과 항 $I g E$ 단일클론항체인 omalizumab, 그리고 항IL-5 단일클 론항체인 mepolizumab가 미국 Food and Drug Administration (FDA)에서 승인을 받았다. 생물학적 제제가 시장에 출시됨에 따라 현재의 CRSwNP의 치료 알고리즘이 바뀌어 야 할 필요가 있고, 생물학적 제제에 적합한 환자를 선정하고 비용-효과적인 면을 고려하여 현재의 의료 시스템을 반영해 야 할 필요가 있다. ${ }^{9)}$

만성 비부비동염은 하나의 획일화된 질환이 아니라 다양한 내재형으로 구성된 질환으로, CRSwNP에서도 내재형이 서로 다르며 임상양상 및 치료에 반응하는 정도도 다양하다. ${ }^{10)}$ 따 라서 CRSwNP의 병태생리와 내재형을 이해하는 것이 생물 학적 제제를 연구하는 출발점이다. 본 종설에서는 CRSwNP 의 병태생리와 내재형에 대하여 기술하고 현재까지 연구 중인
생물학적 제제와 미래의 연구 대상이 될 생물학적제제에 대 해 살펴보고, 앞으로의 치료 알고리즘과 연구 방향 등을 제 시하고자 한다.

\section{만성 비부비동염의 병태생리 및 내재형}

만성 비부비동염과 비용종의 병태생리는 아직 완전히 밝 혀지지 않았지만, 만성 비부비동염의 면역반응은 크게 세 가 지의 염증경로와 내재형으로 분류한다. T helper cell type 1 (Th1), Th2 그리고 Th17 등 3가지의 조력 T세포는 각각 특정 사이토카인의 생성을 촉진하여 만성 염증상태로 이어지며, 각각을 제1형, 제2형 및 제3형 염증반응이라고 한다(Fig. 1). ${ }^{11)}$ 제1형 염증반응의 활성화는 비용종을 동반하지 않는 만성 비 부비동염의 주요한 기전으로, 호중구 침윤이 특징이고 $\mathrm{my}-$ eloperoxidase, interferon (IFN)- $\gamma$, IL-2 및 tumor necrosis factor (TNF) $-\alpha$ 등과 연관이 있다. ${ }^{12,13)}$ 제2형 염증반응은 호 산구성 비용종을 동반하는 만성 비부비동염의 주요 병태생 리로서 호산구 혹은 $\mathrm{IL}-4, \mathrm{IL}-5, \mathrm{IL}-13$ 그리고 $\mathrm{IgE}$ 와 같은

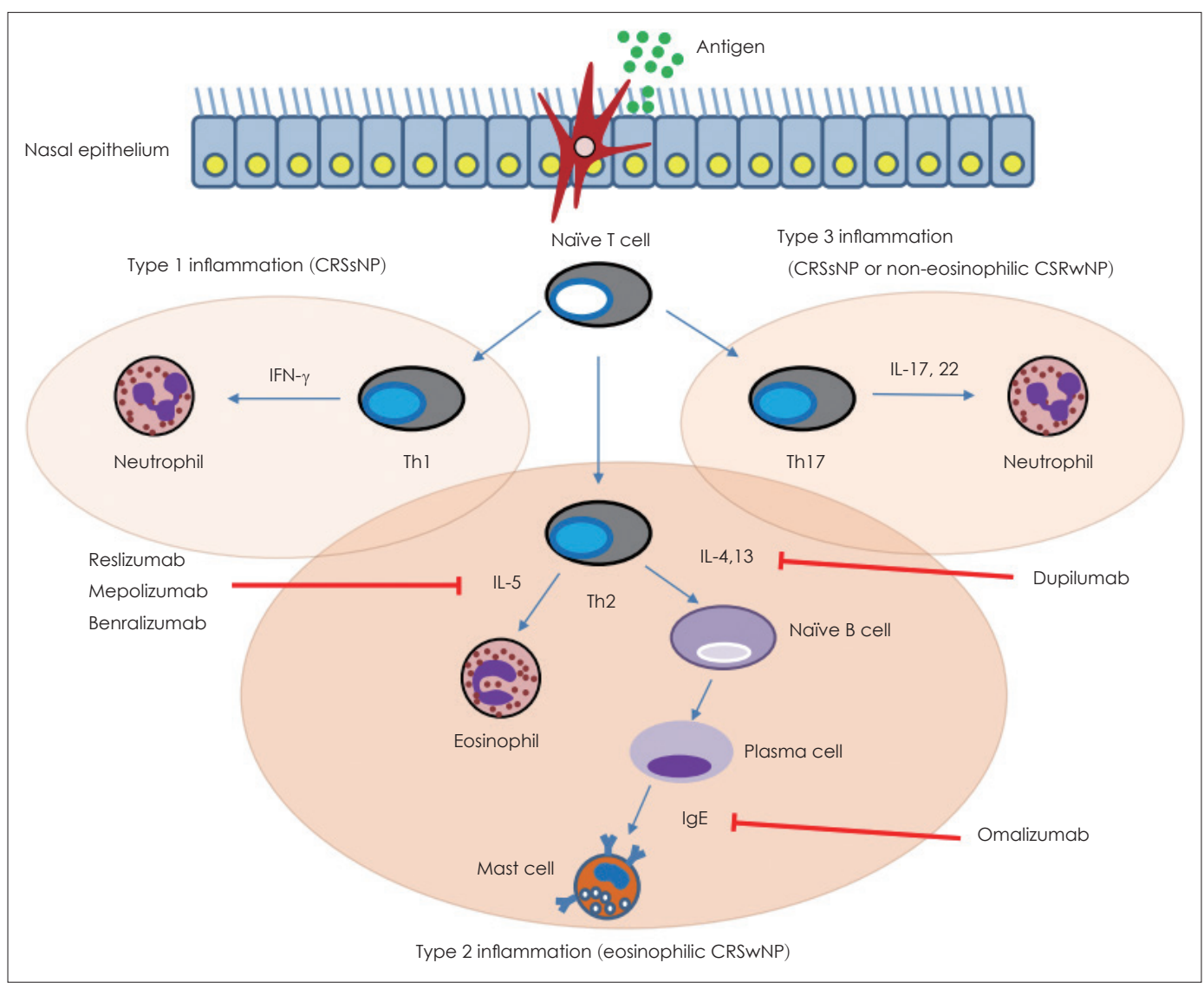

Fig. 1. Overwiew of the pathophysiology of chronic rhinosinusitis and the target at which referred monoclonal antibodies act as inhibitors. CRSsNP, chronic rhinosinusitis without nasal polyps; CRSwNP, chronic rhinosinusitis with nasal polyps; IFN, interferon; Th1, T helper cell type 1; Th2, Thelper cell type 2; Th17, T helper cell type 17; IL, interleukin; IgE, immunoglobulin E. 
신호 전달물질의 불균형 또는 과잉 생산이 특징이다.11) 최근 에는 Th2 세포뿐만 아니라 type 2 innate lymphoid cell (ILC2)가 CRSwNP 조직에서 발현되고, thymic stromal lymphopoietin (TSLP), IL-25, IL-33 등에 의하여 자극받아 IL-4, IL-5와 IL-13을 생산하는 등 Th2 세포와 매우 비슷 한 기능을 하는 것으로 밝혀졌다. ${ }^{14)}$ 따라서 IL-4, IL-5와 IL13 등은 Th2 사이토카인보다는 제2형 사이토카인으로 불리 는 것이 더 적합하며, CRSwNP에서 매우 중요한 바이오마 커이다. ${ }^{11)}$ 제 3 형 염증반응은 Th17 세포에 의한 IL-6, IL-17, $\mathrm{IL}-22$ 및 TNF- $\alpha$ 등의 높은 수치와 연관이 있고, 호중구 세 포의 침윤이 두드러진 비호산구성 비용종을 동반한 만성 비 부비동염과 관련 있다. ${ }^{12,13)}$

CRSwNP은 서양인에서 대부분 제2형 염증반응에 의하여 호산구성 비용종을 동반한 만성 비부비동염으로 나타나며 천 식이 주로 동반되는 특성을 지니고 있지만, 동양인의 CRSwNP 은 40\%-60\%에서 제3형 염증반응에 의한 비호산구성 비용 종을 동반한 만성 비부비동염으로 나타나며 천식을 잘 동반 하지 않는다. ${ }^{15,16)}$ 우리나라를 포함한 동양인의 경우 CRSwNP 내에서도 다른 내재형을 갖고 있어 그에 따라 질병의 본질, 임상양상 및 치료 방법 등이 완전히 달라질 수 있다. 따라서 CRSwNP의 내재형을 이해하고 이를 통해 환자를 분류하는 것은 환자 개개인에 맞춤화된 치료에 중요하다.

\section{최근 연구동향 및 현재 개발 중인 생물학적 제제}

\section{최근 연구동향}

CRSwNP의 고전적인 치료방법으로는 전신 혹은 비강내 국소 스테로이드제 사용과 부비동 내시경수술이 있으나, 추 후 재발하는 등 조절하기 어려운 경우가 많아 대체요법이 필 요하다. CRSwNP 병태생리에 대한 이해가 발전하면서 만성 염증의 연결고리를 끓을 잠재력을 갖고 있는 효과기 세포나 염증 매개체를 밝히고 이를 표적으로 하는 단일클론항체에 대한 연구가 진행되고 있다.

생물학적 제제는 천식이나 아토피 피부염 등과 같은 다양 한 알레르기-매개 질환에 대한 혁신적인 치료법으로 사용되 어 지난 15 년 동안 고무적인 결과를 보였고, ${ }^{7)} \mathrm{CRSwNP}$ 의 병 태생리는 천식의 병태생리와 겹치는 부분이 많다. 두 질환의 병태생리가 모두 제2형 염증반응 및 호산구 침윤이라는 부 분이 공통점이며, 최근 수년간 CRSwNP에 대하여 개발되고 있는 여러 생물학적 제제는 제2형 염증반응을 억제하는 역 할을 한다. ${ }^{17-19)}$ 현재 호산구성 CRSwNP에 대한 여러 단일클 론항체가 연구 중이며, 조절되지 않는 CRSwNP에서 치료 효
과를 보이고 있다(Table 1). 대표적으로 IL-4 receptor $\alpha$ 에 대한 단일클론항체인 dupilumab은 치료 효과를 인정받아 2019년 6월에 미국 FDA의 승인을 받았으며, 조절되지 않는 성인 CRSwNP에서 사용할 수 있다. 이후 IgE를 표적으로 작 용하는 단일클론항체인 omalizumab과 IL-5에 대한 단일클 론항체인 mepolizumab도 성인 CRSwNP 환자를 치료하기 위한 보조요법으로 각각 2020년 12월과 2021년 7월에 미국 $\mathrm{FDA}$ 의 승인을 받았다. 그 외 다른 단일클론항체들은 아직 $\mathrm{FDA}$ 의 승인을 받지는 못하였으나 효능과 안전성에 대해 평 가 중이다.

현재까지 비호산구성 CRSwNP에 대하여 연구중인 생물 학적 제제는 없다. 앞서 언급했듯이 우리나라 CRSwNP 환자 의 절반 정도가 호중구 침윤이 특징인 비호산구성 비용종을 동반한 CRSwNP 환자이다. 따라서 현재 개발 중인 생물학적 제제가 우리나라 CRSwNP 환자의 치료에 갖고 있는 한계점 이 있으며, 현재 개발된 생물학적 제제를 치료로 사용할 때 적합한 내재형의 환자를 선별하는 것이 중요하다.

\section{항 $\mathrm{IgE}$ 단일클론항체}

$\mathrm{IgE}$ 는 항원에 대한 반응으로 $\mathrm{B}$ 세포에 의하여 생성되며, $\mathrm{Th} 2$ 세포에 의하여 분비되는 사이토카인인 IL-4와 IL-13의 영향을 받는다. $\mathrm{IgE}$ 는 비만세포에 발현하는 FceRI와 CD23 등의 수용체에 결합하여 히스타민 등 기형성된 매개체를 분 비하고 cysteinyl leukotriene과 prostaglandin 등을 생성한 다. ${ }^{20)}$ Omalizumab은 IgE에 대한 단일클론항체로서 유리 $\mathrm{IgE}$ 에 부착하여 $\operatorname{IgE}$ 가 비만세포에 결합하는 것을 억제한다. Omalizumab은 비교적 연구가 많이 진행된 생물학적 제제로 천식과 같은 알레르기 질환의 치료에 효과적이며, ${ }^{21)}$ 2003년 에는 코르티코스테로이드 흡입치료로 적절히 조절되지 않는 12세 이상의 중등도 및 중증 천식 환자에게 omalizumab을 사용할 수 있도록 FDA 승인을 받았다. 이후 CRSwNP에 대 한 omalizumab의 치료 효과를 발표한 연구 중 대표적인 무 작위 대조군 연구는 다음과 같다. Gevaert 등 ${ }^{18)}$ 은 이중맹검 무작위 대조군 연구에서 24명의 중증 천식이 있는 CRSwNP 환자를 대상으로 2 주 또는 4 주 간격으로 총 16 주 동안 혈청 총 $\mathrm{IgE}$ 와 체중에 따라 omalizumab을 피하주사하여(최대 $375 \mathrm{mg}$ ) 8명의 대조군과 비교하였다. 대조군에 비하여 치료 군에서 비용종 점수가 감소하고 코증상 점수가 호전되는 등 유의미한 치료 효과를 보였다. 하지만 이 연구는 천식을 동반 한 CRSwNP 환자를 대상으로 하였기 때문에 결과를 모든 $\mathrm{CRSwNP}$ 환자로 일반화할 수 없는 한계점이 있다. ${ }^{18)}$

지난 2020년 12월에 omalizumab은 18세 이상의 CRSwNP 환자를 치료하기 위한 보조 유지치료로 FDA 승인을 받았다. 


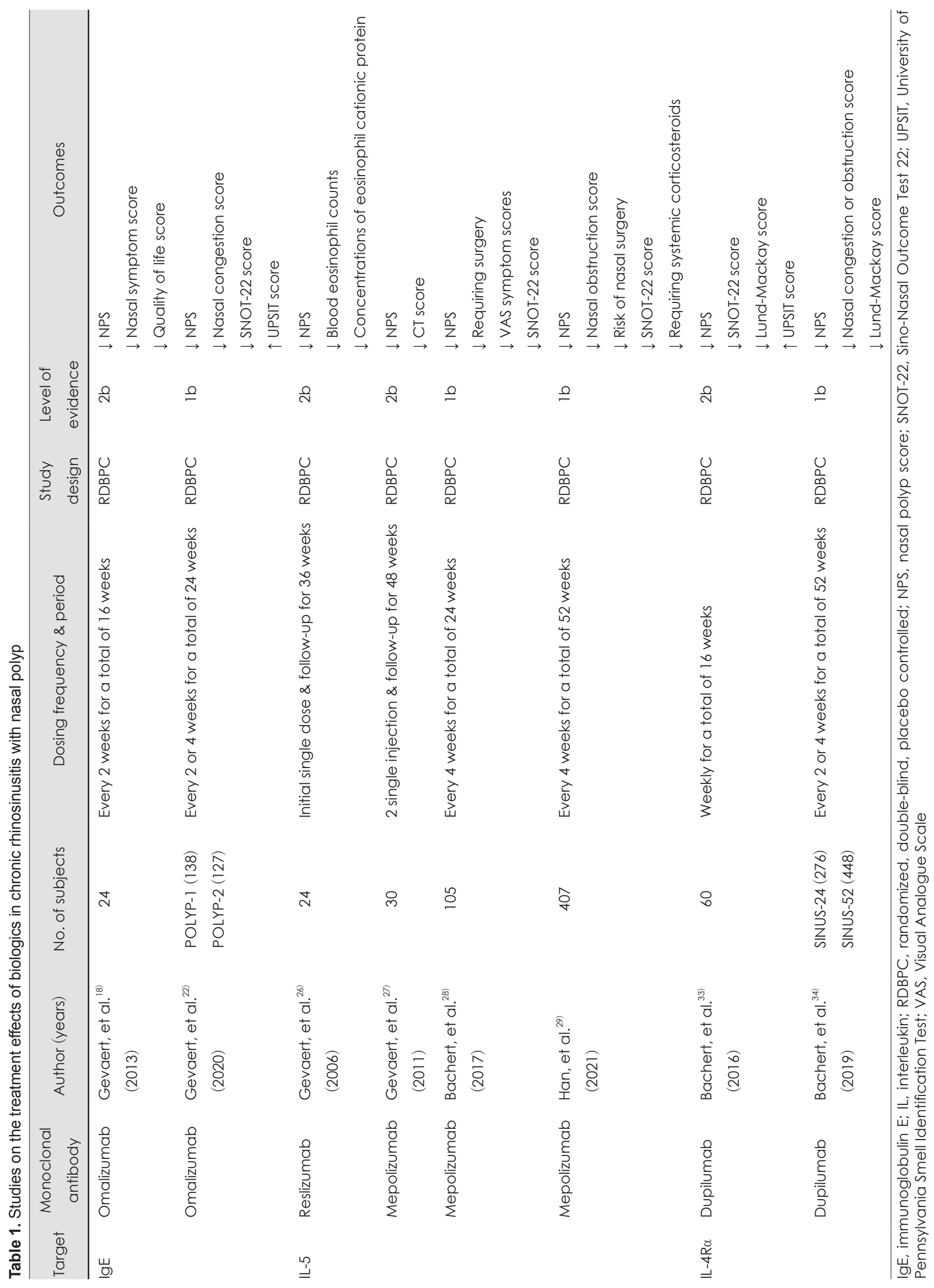


이를 가능하게 한 것이 Gevaert 등2이 보고한 대규모 3상 임상시험인 POLYP-1과 POLYP-2이다. 비강 내 스테로이드 치료에 치료 효과가 없는 CRSwNP 환자 138명과 127명을 대상으로 하여 omalizumab 치료군과 위약군을 비교하였다. 24주간의 치료 후에 두 그룹 모두 omalizumab 치료군에서 대조군에 비해 비용종 점수 및 코막힘 점수가 유의하게 감소 하였고, Sino-Nasal Outcome Test 22 (SNOT-22), University of Pennsylvania Smell Identification Test (UPSIT) score, 총 코증상 점수 및 후각 소실, 후비루, 콧물 점수 등에서도 유의한 치료 효과를 보였다. 부작용으로는 두통, 비인두염, 주사부위의 문제(발적, 통증 등) 및 천식 악화 등이 보고되었 으나, 치료군과 대조군에서 유의한 차이를 보이지 않았다.

\section{항IL -5 단일클론항체}

IL-5는 호산구의 국소 유입, 성숙 및 생존을 조절하는 제2 형 사이토카인으로서, Th2 세포, 비만세포 및 ILC2 세포 등 에 의하여 분비된다. ${ }^{23)}$ Tomassen 등 ${ }^{24}$ 은 만성 비부비동염의 표현형과 다양한 면역 사이토카인과의 관계에 대하여 분석 하여 비용종과 IL-5의 연관성을 확인하였다. 만성 비부비동 염 환자를 IL-5의 수치에 따라 높은 군, 중등도 군 및 낮은 군 등 3 개의 군으로 분류하였고, 높은 군에서 비용종 및 천 식의 유병률이 가장 높았고, 낮은 군에서는 대부분 비용종 을 동반하지 않았다. 따라서 천식 환자의 치료와 마찬가지로 CRSwNP 환자에 대하여 생물학적 치료의 타겟으로 IL-5를 연구하였다.

CRSwNP 환자의 치료제로 연구된 IL-5에 대한 항체는 mepolizumab, reslizumab, 그리고 benralizumab 등이 있다. Mepolizumab과 reslizumab은 IL-5에 대한 단일클론항체로 서 IL-5에 결합하여 신호를 억제하고, 반면 benralizumab은 IL-5 수용체에 작용한다. ${ }^{25)}$ 2006년에 Gevaert 등 ${ }^{26}$ 이 CRSwNP 환자에 대한 reslizumab의 치료 효과를 실험한 연구에서 대 조군에 비교하여 치료군의 비용종 점수와 혈액 내 호산구가 유의하게 감소하였다. 또한 치료 효과를 보인 환자에서 치료 효과가 없는 환자에 비해 코 분비물의 IL-5가 증가하였고, 따 라서 증가되어 있는 IL-5는 항IL-5의 치료 효과를 예측할 수 있는 요인이라고 설명하였다. 2011년 보고된 mepolizumab 에 대한 연구에서는 mepolizumab $750 \mathrm{mg}$ 을 28일 간격으로 2 차례 정맥주사한 후 48 주간 추적 관찰하며 대조군과 비교 하였고, 치료군에서 비용종 크기와 CT 점수 모두 대조군에 비교하여 현저히 감소하였다. ${ }^{27)}$ 이후 2017년에 Bachert 등 28 은 mepolizumab을 이용한 더 큰 규모의 임상연구를 보고하였 다. 국소 스테로이드제 치료에 반응이 없는 105명의 CRSwNP 환자에 mepolizumab $750 \mathrm{mg}$ 을 4주 간격으로 24주간 정맥
주사하여 대조군과 비교하였고, 치료군에서 내시경 비용종 점수, 비용종 시각 아날로그척도 점수, 코증상 점수 및 SNOT22 등에서 유의한 호전을 보였고 궁극적으로 수술이 필요한 환자의 수가 감소하였다. ${ }^{28)}$

Mepolizumab과 benralizumab은 12세 이상의 심한 호산 구성 천식 환자에서 추가 유지치료로 사용할 수 있도록 각각 2015년과 2017년에 FDA로부터 승인을 받았고, reslizumab은 18세 이상의 심한 천식 환자에 대한 유지치료제로서 2016년에 $\mathrm{FDA}$ 의 승인을 받았다. 이후 $\mathrm{Han}$ 등 ${ }^{29}$ 의 대규모의 3상 임상 시험의 결과를 바탕으로 mepolizumab은 2021년 7월에 성인 CRSwNP 환자의 보조치료로 사용할 수 있도록 미국 FDA 의 승인을 받았다. 조절되지 않는 CRSwNP 환자 407명을 대상으로 206명은 mepolizumab을 4주 간격으로 총 52주간 $100 \mathrm{mg}$ 피하주사하였고 201명은 위약을 투약하였다. Mepolizumab 치료군에서 대조군에 비교하여 비용종 점수가 유의 하게 감소하였고 비폐색 점수도 유의하게 호전되었다. 그리고 대조군에서 부비동 수술과 전신적 스테로이드 투약이 필요한 경우가 유의하게 적었으며, SNOT-22, 코증상 시각 아날로그 척도 점수 및 후각 소실 등에서도 유의하게 호전되었다. 그러 나 mepolizumab 치료를 받은 그룹에서 치료와 관련된 중대 이상반응은 보고되지 않았다.

\section{항IL-4Ra 단일클론항체}

$\mathrm{IL}-4$ 와 IL-13은 IL-5와 마찬가지로 제2형 염증반응의 사 이토카인으로 $\mathrm{B}$ 세포 활성화와 $\mathrm{IgE}$ 와 같은 면역글로불린의 국소 생산을 통해 Th2 반응을 촉진한다. ${ }^{30,31)}$ Dupilumab은 $\mathrm{IgG} 4$ 단일클론항체로서, IL-4 receptor $\alpha$ 수용체 서브유닛에 특이적으로 결합하여 IL-4 및 IL-13 신호전달을 차단한다. ${ }^{32)}$ 제2형 염증반응의 조절에 효과적이며 2019년 6월에 dupilumab은 조절되지 않는 성인 CRSwNP 환자의 치료로 FDA 승인을 받았다. 이는 CRSwNP 환자의 치료에 대하여 가장 먼저 FDA 승인을 받은 생물학적 제제이다.

Bachert 등 ${ }^{33)}$ 은 2016년도에 처음으로 CRSwNP 환자에서 dupilumab 치료 효과를 보고하였다. 미국과 영국에서 양측 비강의 심한 비용종 소견을 보이는 60 명의 성인 $\mathrm{CRSwNP}$ 환 자를 대상으로 연구하였고, 대조군에 비하여 치료군에서 유 의하게 SNOT-22, 후각, 코막힘 및 울혈, 비용종 점수 및 천 식 조절 등의 항목에서 개선을 보였고 심각한 부작용은 없었 다. 2019년에는 dupilumab의 효능과 안전성을 조사한 두 개 의 대규모 다기관 무작위 대조군 연구가 보고되었다. ${ }^{34}$ SINUS-24 임상연구에는 총 276명의 환자가 등록되었고, 143 명 은 dupilumab을 2주마다 24주간 투약하였고 133명은 위약 군이었다. SINUS-52 임상연구에는 448명의 환자가 등록되 
었으며, 150 명의 환자는 2 주마다 52 주 동안, 145 명의 환자는 2주마다 24주 투약 후 4주씩 총 52주, 나머지 153명은 위약 군이었다. Dupilumab으로 치료를 받은 그룹에서 위약군에 비하여 비용종 크기, Lund-Mackey 점수, 코막힘, 울혈 및 후각 등에서 유의하게 좋은 결과를 보여 추가적인 전신 스테 로이드제 사용이나 수술적 치료의 필요성이 감소하였다. 비 인두염, 천식 악화, 두통, 코피 등의 부작용이 오히려 위약군 에서 더 많이 보였다. 그러나 임상시험에 대한 포함 기준은 경구 스테로이드제 혹은 부비동수술에 실패한 중증 CRSwNP 환자로 제한되었기 때문에 경증 및 중등도 CRSwNP 환자에서 dupilumab 치료의 효과나 역할에 대한 것은 명확하지 않다. 따라서 최선의 치료 과정을 결정하기 위 해서는 사전에 받은 치료나 환자의 선호도, 치료 비용 및 질 병 중증도 등을 고려하여 심층적이고 개별화된 논의가 필요 하다.

\section{생물학적 제제의 효과 비교}

생물학적 제제의 치료효과를 보고한 임상시험의 결과를 바탕으로 각 생물학적 제제를 비교하고자 하는 연구가 보고 되었다. 비록 생물학적 제제들을 직접적으로 비교한 것은 아 니지만, Helling 등 ${ }^{35)}$ 은 omalizumab, mepolizumab, 그리고 dupilumab에 대한 2상 및 3상 임상시험의 결과를 바탕으로 세 가지 생물학적 제제의 치료 효과를 간접적으로 비교 분석 하였다. SNOT-22, 코막힘 점수, 후각 소실 점수, 후각 검사 점수, Lund-Mackay CT 점수 및 비용종 점수 등 6가지 항 목을 이용하였고, 세 가지 생물학적 제제 모두 조절되지 않는 CRSwNP 환자에서 각 항목에 대한 유의한 치료 효과가 있 다고 결론지었다. 그 중에서 후각은 후각 소실 점수 및 후각 검사 점수 모두에 대하여 dupilumab의 효과가 다른 두 생물 학적 제제보다 우수하다고 보고하였다. 각 연구들에서 사용 한 증상의 측정 방법과 검사 방법들이 다르다는 한계점이 있 고 후각 외에는 치료 효과가 의미 있는 차이를 보이지는 않 았지만, 궁극적으로 생물학적 제제 간의 직접적인 비교는 치 료 프로토콜을 개선하는 데에 필요하며 추후 연구해야 할 부분이다.

\section{개발 가능성 있는 단일클론항체}

\section{항TSLP}

TSLP는 상피세포-유래 사이토카인으로서 아토피 피부염, 기관지 천식 및 CRSwNP와 같은 Th2 관련 염증성 질환의 병인에 관여한다. ${ }^{36)} \mathrm{Wang}$ 등 ${ }^{37)}$ 은 호산구성 $\mathrm{CRSwNP}$ 환자의
코상피세포를 분석하여, TSLP가 STAT3의 인산화를 촉진하 여 Th2 염증 마커인 eotaxin-1의 발현을 증가시킴을 보고하 였다. Nagarkar 등인 은 TSLP가 비용종에서 증가하고 부비동 점막조직의 Th2 염증 마커와 상관관계가 있음을 분석하여 TSLP의 과잉생산이 CRSwNP의 병태생리에 기여한다고 보 고하였다. Liu 등 ${ }^{38}$ 도 94 명의 CRSwNP 혹은 알레르기비염 환자를 대상으로 분석하여 비용종 환자의 코상피세포에서 TSLP가 높은 수준으로 관찰되며 CRSwNP의 병태생리에 TSLP가 관여한다고 주장하였다. 항TSLP 단일클론항체인 tezepelumab은 중등도 및 중증 천식 환자에서 효과가 있다 는 2상 이중맹검 무작위 대조군 연구가 보고된 바는 있지만, 아직 CRSwNP 환자 내에서 효과를 조사한 연구는 없다. ${ }^{39)}$

\section{항IL-33}

IL-33은 IL-1 사이토카인 계열에 속하며 코상피조직이나 림프 기관에서 발현되어 알레르기 질환의 병인에 중요한 역 할을 한다. IL-33 수용체가 높게 발현되어 있는 Th2 세포나 호산구, 비만세포, 호염기구 등과 같은 다양한 염증세포를 활 성화시켜 염증반응을 유발하며, 제2형 염증반응에서 중요한 $\mathrm{IL}-5$ 와 IL-13의 생성을 촉진하고 ILC2 세포의 기능을 조절 한다. ${ }^{40-42)}$

$\mathrm{Kim}$ 등 $^{40)}$ 은 CRSwNP 환자의 코점막조직에서 대조군 및 $\mathrm{CRSsNP}$ 환자의 조직에서 보다 IL-33의 농도가 증가하여 $\mathrm{CRSwNP}$ 의 병태생리에서 중요한 역할을 한다고 보고하였다. Song 등 ${ }^{41}$ 과 Luo 등 ${ }^{42)}$ 의 연구에서도 CRSwNP의 비용종 조 직에서 IL-33 수치가 유의하게 증가하였고 IL-33이 CRSwNP 의 병태생리에서 중요한 역할을 할 것이라고 제시하였다. 현 재까지 CRSwNP 환자에서 항IL-33 치료의 효과를 연구한 무작위 대조군 연구는 없지만 1 상 및 2상의 임상연구가 진행 중이다.

\section{생물학적 제제의 치료 적응증 및 반응 평가}

CRSwNP 환자에서 생물학적 제제의 처방에 대한 가이드 라인은 2019년에 European Forum for Research and Education in Allergy and Airway Diseases (EUFOREA)에서 제시하였다.' 크게는 부비동 수술을 받은 병력이 중요하며, 그 외에 다음 5 가지의 기준을 근거로 생물학적 제제 사용을 결정하도록 가이드라인을 제시하였다. 세부적인 기준으로는 제2형 염증반응의 근거(생물학적 바이오마커)가 있는지, 과 거 2년간 전신 스테로이드제 치료를 받은 적이 있는지, 심각 한 삶의 질 장애가 발생하였는지, 후각 저하 유무, 천식 동반 
유무 등의 5가지이다. 이후 European Position Paper on Rhinosinusitis and Nasal Polyps 2020 (EPOS 2020)에서 각각 의 기준들에 대하여 구체적인 세부기준을 보완하여 처방 가 이드라인을 다시 제시하였다(Fig. 2). ${ }^{43)}$

부비동 수술을 받은 병력이 있는 CRSwNP 환자는 5가지 세부기준 중 3 가지를 만족하면 생물학적 제제 치료의 적응증 이 되며, 이는 EUFOREA와 EPOS 2020에서 모두 동일하다. 그러나 수술을 받은 병력이 없는 경우는 다소 논란의 여지가 있으며, 생물학적 제제가 수술의 필요성을 줄여줄 수 있을 정 도로 치료 효과가 있는지가 불분명하기 때문이다. 최근 생물 학적 제제로 치료하여 비용종의 크기와 정도에서 효과가 있었 다는 연구들이 있으나, 실제로 많은 수의 환자에서 여전히 수 술적 치료가 추가적으로 필요하다. ${ }^{44-46)}$ 그럼에도 불구하고 반 복적인 수술적 치료만으로 제2형 염증반응에 의한 CRSwNP 환자의 재발성 비용종을 완전히 치료하거나 예방할 수 없기 때 문에 생물학적 제제는 현재 수행되고 있는 부비동 수술의 대안 이 될 것이라는 의견도 있다. 실제로 천식을 동반한 CRSwNP 환자에게 omalizumab과 수술군으로 나누어 비교한 연구에 서 omalizumab 치료 16주 후에 SNOT-22 감소 정도는 수술 군과 대등한 치료 효과를 보였다. ${ }^{47)} \mathrm{EUFOREA}$ 에서는 수술 을 받은 병력이 없는 CRSwNP 환자에서 생물학적 제제의 역 할은 어느정도 논란이 있을 수 있겠으나, 앞선 5가지 세부기 준 중 4가지를 만족하면 생물학적 제제를 고려해볼 수 있다
고 제시하였다. 반면에, EPOS 2020에서는 생물학적 제제의 적응증을 내시경 부비동수술을 받은 병력이 있는 CRSwNP 환자로 제한하고 있다. 한편, EUFOREA에서 제시한 생물학 적 제제 치료의 대상이 될 수 없는 환자는 $\mathrm{CRSsNP}$ 이거나 제 2형 염증반응의 증거가 없는 경우, 낭포성 섬유증 환자, 일측 비용종 환자, 점액낭종 환자, 면역저하자 등 생물학적 치료의 금기증이 있는 환자, 치료에 순응도가 좋지 않은 환자이다.

치료에 대한 반응을 평가하는 것도 치료에 적합한 환자를 선정하는 것만큼이나 중요하며, 생물학적 제제의 치료에 효과 가 없는 경우에는 치료를 불필요하게 지속하는 것은 피해야 한다. EUFOREA에는 생물학적 제제 사용 중 평가포인트에 대한 가이드라인도 제시하였다. ${ }^{9)}$ 다섯 가지의 항목, 즉 비용종 크기 감소, 경구 코르티코스테로이드제 사용 감소, 삶의 증 향상, 후각 향상, 동반 질환들의 영향 감소 등을 제시하였고, 치료 16주 후에 측정하여 만족시키는 항목 수에 따라 치료반 응 정도를 평가할 것을 제안하였다. 치료반응의 결과에 따라 치료를 유지할지 결정할 수 있으며, 16 주라는 기준은 추후 연구에 따라 변경될 수 있다.

\section{우리나라에서 생물학적 제제 현황 및 추후 연구 방향}

CRSwNP 환자의 치료제로 우리나라에서 사용 가능한 생

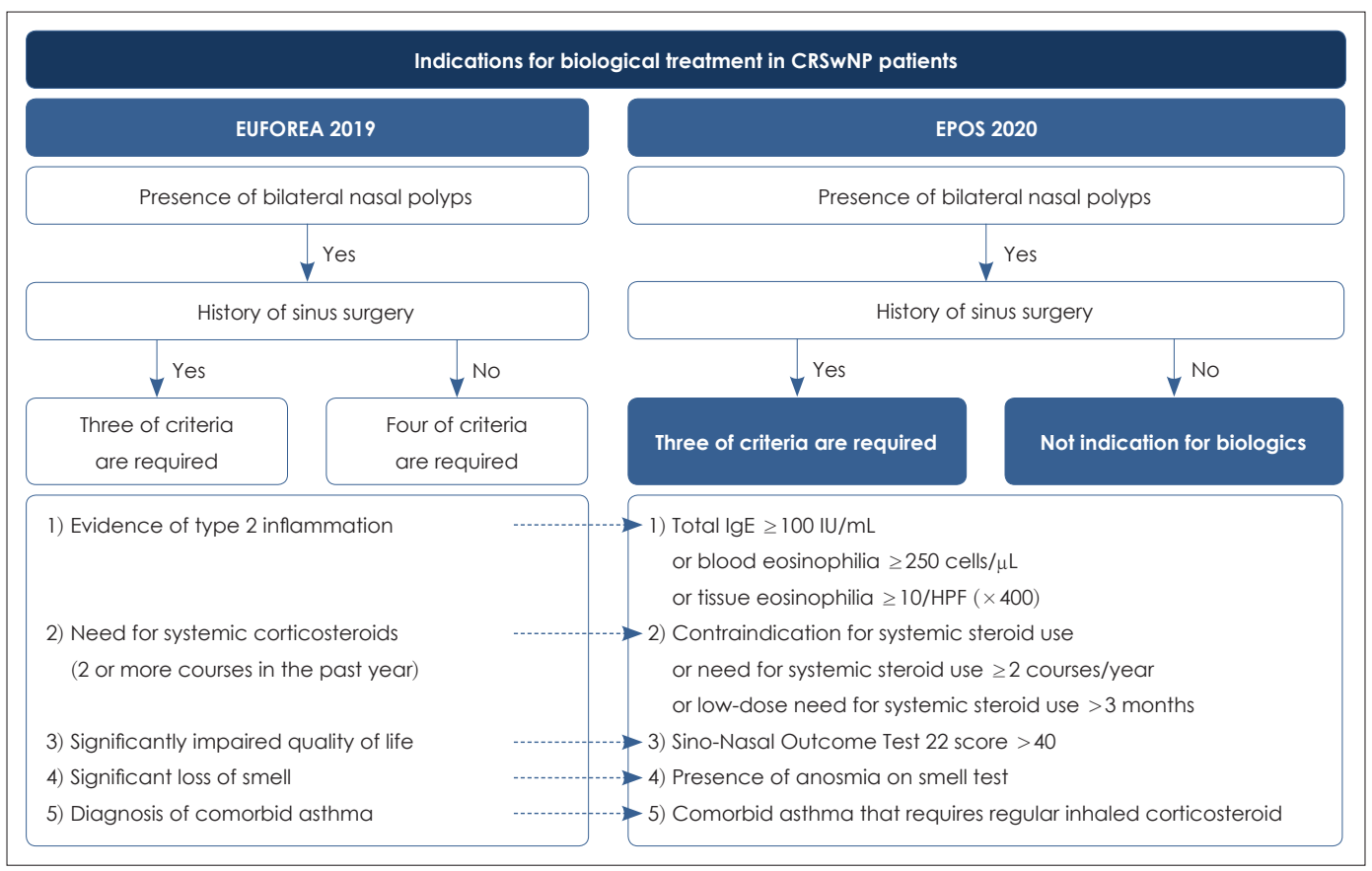

Fig. 2. Indications for biologics in the treatment of CRSwNP; guideline of the EUFOREA and EPOS 2020. CRSwNP, chronic rhinosinusitis with nasal polyp; EUFOREA, European Forum for Research and Education in Allergy and Airway Diseases; EPOS, European Position Paper on Rhinosinusitis and Nasal Polyps. 
물학적 제제는 Dupixent ${ }^{\circledR}$ (dupilumab; Regeneron Pharmaceuticals Inc., Tarrytown, NY, USA)과 Xolair ${ }^{\circledR}$ (omalizumab; Novartis, Basel, Switzerland) 두 가지이며, 둘 다 만 18 세 이상 성인에서 기존치료에 적절하게 조절되지 않는 비 용종을 동반한 만성 비부비동염의 추가 유지치료에 적용이 허가되었다. Dupixent ${ }^{\circledR}$ 는 2주 간격으로 $300 \mathrm{mg}$ 을 피하 주 사하며 총 투여 기간은 정해져 있지 않다. Xolair ${ }^{\circledR}$ 는 체중 및 초기 혈중 $\operatorname{IgE}$ 수치에 따라 1회 투여 용량이 75-600 mg으 로 다르며, 2주 혹은 4주 간격으로 피하 주사한다. 아직까지 CRSwNP 환자에 대하여 두 약제는 모두 보험 비급여이며, 아 토피 피부염 혹은 천식에 대해서만 조건을 만족할 경우 급여 가 가능하다. 비급여 수가는 Dupixent ${ }^{\circledR} 300 \mathrm{mg}$ 이 710000원, Xolair $^{\circledR} 150 \mathrm{mg}$ 이 271700 원이며, 치료 간격이나 기간에 따라 상이하겠으나 1년에 400-1000만 원 이상의 비용이 드는 비 교적 고가 치료 방법이다. 적응증은 비교적 폭넓게 제시가 되 어 있지만 수술에 비하여 비용-효과적인 면에서 좋지 않은 것은 사실이며, 어떠한 환자군을 대상으로 투약할 지에 대하 여 신중한 접근이 필요하다.

앞으로는 CRSwNP 환자 치료로 생물학적 제제의 역할을 정립하고 투약 방법, 투약 기간 및 종료 기준 등에 대한 연구 가 필요하다. 여러 연구에서 2주 혹은 4주 간격으로 투약을 하였으나 치료 기간은 16 주, 24주 및 52 주 등으로 매우 상이 하며, 총 치료 기간을 얼마로 예상하고 치료를 시작할지, 그리 고 어떠한 기준으로 치료를 종료하는지 등에 대하여는 아직 제시되어 있지 않다. 따라서 이에 대한 추가적인 임상연구가 필요하고 우리나라 의료실정 및 환자 성격에 맞게 정립해야 할 필요가 있다. 그 외에도 수술 전에 대체치료로 시행하는 것과 수술 후에 유지치료로 시행하는 것에 대한 효과를 비교 하고 환자에 따라 선택할 수 있는 기준을 제시하는 연구도 필요하다.

제2형 염증반응을 보이는 CRSsNP에 대한 생물학적 제제 의 치료 효과, 생물학적 제제에 반응이 좋은 환자에서 바이오 마커가 보이는 특징, 동양인에게 많은 비호산구성 CRSwNP 환자에 대한 효과적인 타겟 사이토카인 연구 등도 장기적으 로 풀어야 할 숙제이다.

\section{결 론}

고전적인 치료로 조절하기 어려운 CRSwNP 환자 치료는 이비인후과 의사에게는 해결해야 할 과제이다. 생물학적 제 제가 이러한 환자에게 새로운 치료가 될 수 있음을 보여주는 긍정적인 연구결과가 보고되고 있으며, dupilumab과 omalizumab은 잘 조절되지 않는 CRSwNP 환자를 대상으로 사
용되기 시작하였다. 하지만 환자 선택과 치료 프로토콜 등에 대한 보완이 필요하며, 대규모의 장기간 추적 관찰 기간을 갖는 전향적인 연구가 향후 필요하다. 그럼에도 불구하고, $\mathrm{CRSwNP}$ 의 치료 내에서 생물학적 제제의 역할과 치료 알고 리즘이 정립되고 비용-효과적인 측면이 개선된다면, 생물학 적 제제는 고전적인 치료로 조절되지 않는 CRSwNP 환자에 있어서 새롭고 효과적인 치료이다.

\section{Acknowledgments}

None.

\section{Author Contribution}

Conceptualization: all authors. Data curation: Jee Won Moon. Formal analysis: all authors. Investigation: Su-Jong Kim, Jee Won Moon. Methodology: Heung-Man Lee. Project administration: SuJong Kim, Heung-Man Lee. Software: Jee Won Moon. Supervision: Heung-Man Lee. Validation: Heung-Man Lee. Visualization: SuJong Kim, Jee Won Moon. Writing - original draft: Su-Jong Kim. Writing - review \& editing: Heung-Man Lee, Jee Won Moon.

\section{ORCIDs}

Heung-Man Lee https://orcid.org/0000-0003-4774-4739

Su-Jong Kim https://orcid.org/0000-0003-1801-0656

\section{REFERENCES}

1) Ahn JC, Kim JW, Lee CH, Rhee CS. Prevalence and risk factors of chronic rhinosinusitus, allergic rhinitis, and nasal septal deviation: Results of the Korean National Health and Nutrition Survey 20082012. JAMA Otolaryngol Head Neck Surg 2016;142(2):162-7.

2) Fokkens WJ, Lund VJ, Mullol J, Bachert C, Alobid I, Baroody F, et al. EPOS 2012: European position paper on rhinosinusitis and nasal polyps 2012. A summary for otorhinolaryngologists. Rhinology 2012;50(1):1-12.

3) Benjamin MR, Stevens WW, Li N, Bose S, Grammer LC, Kern RC, et al. Clinical characteristics of patients with chronic rhinosinusitis without nasal polyps in an academic setting. J Allergy Clin Immunol Pract 2019;7(3):1010-6.

4) Loftus CA, Soler ZM, Koochakzadeh S, Desiato VM, Yoo F, Nguyen SA, et al. Revision surgery rates in chronic rhinosinusitis with nasal polyps: Meta-analysis of risk factors. Int Forum Allergy Rhinol 2020;10(2):199-207.

5) Busse WW. Anti-immunoglobulin E (omalizumab) therapy in allergic asthma. Am J Respir Crit Care Med 2001;164(8 Pt 2):S12-7.

6) Pauwels B, Jonstam K, Bachert C. Emerging biologics for the treatment of chronic rhinosinusitis. Expert Rev Clin Immunol 2015;11(3):349-61.

7) Fajt ML, Wenzel SE. Biologic therapy in asthma: Entering the new age of personalized medicine. J Asthma 2014;51(7):669-76.

8) Langdon C, Mullol J. Nasal polyps in patients with asthma: Prevalence, impact, and management challenges. J Asthma Allergy 2016;9:45-53.

9) Fokkens WJ, Lund V, Bachert C, Mullol J, Bjermer L, Bousquet J, et al. EUFOREA consensus on biologics for CRSwNP with or without asthma. Allergy 2019;74(12):2312-9.

10) Song Y, Cho SW. Biomarkers in chronic rhinosinusitis with nasal polyp: Personalized medicine based on endotype. Korean J Otorhinolaryngol-Head Neck Surg 2019;62(8):427-34.

11) Bachert C, Gevaert P, Hellings P. Biotherapeutics in chronic rhinosinusitis with and without nasal polyps. J Allergy Clin Immunol 
Pract 2017;5(6):1512-6

12) Huang Z, Nayak JV, Sun Y, Huang Q, Zhou B. Peripheral blood T-helper cells and eosinophil populations in patients with atopic and nonatopic chronic rhinosinusitis. Am J Rhinol Allergy 2017; 31(1):8-12.

13) Akdis CA, Bachert C, Cingi C, Dykewicz MS, Hellings PW, Naclerio RM, et al. Endotypes and phenotypes of chronic rhinosinusitis: A PRACTALL document of the European Academy of Allergy and Clinical Immunology and the American Academy of Allergy, Asthma \& Immunology. J Allergy Clin Immunol 2013;131(6):147990.

14) Poposki JA, Klingler AI, Tan BK, Soroosh P, Banie H, Lewis G, et al. Group 2 innate lymphoid cells are elevated and activated in chronic rhinosinusitis with nasal polyps. Immun Inflamm Dis 2017;5(3):233-43

15) Mahdavinia M, Suh LA, Carter RG, Stevens WW, Norton JE, Kato A, et al. Increased noneosinophilic nasal polyps in chronic rhinosinusitis in US second-generation Asians suggest genetic regulation of eosinophilia. J Allergy Clin Immunol 2015;135(2):576-9.

16) Yang JH, Kim DK. New discoveries regarding endotypes of chronic rhinosinusitis with nasal polyp. Korean J Otorhinolaryngol-Head Neck Surg 2017;60(9):431-6.

17) Hong CJ, Tsang AC, Quinn JG, Bonaparte JP, Stevens A, Kilty SJ. Anti-IgE monoclonal antibody therapy for the treatment of chronic rhinosinusitis: A systematic review. Syst Rev 2015;4:166.

18) Gevaert P, Calus L, Van Zele T, Blomme K, De Ruyck N, Bauters $\mathrm{W}$, et al. Omalizumab is effective in allergic and nonallergic patients with nasal polyps and asthma. J Allergy Clin Immunol 2013;131(1): 110-6.e1.

19) Pinto JM, Mehta N, DiTineo M, Wang J, Baroody FM, Naclerio RM. A randomized, double-blind, placebo-controlled trial of antiIgE for chronic rhinosinusitis. Rhinology 2010;48(3):318-24.

20) Bachert C, Zhang N, Hellings PW, Bousquet J. Endotype-driven care pathways in patients with chronic rhinosinusitis. J Allergy Clin Immunol 2018;141(5):1543-51.

21) Busse W, Corren J, Lanier BQ, McAlary M, Fowler-Taylor A, Cioppa GD, et al. Omalizumab, anti-IgE recombinant humanized monoclonal antibody, for the treatment of severe allergic asthma. $\mathrm{J}$ Allergy Clin Immunol 2001;108(2):184-90.

22) Gevaert P, Omachi TA, Corren J, Mullol J, Han J, Lee SE, et al. Efficacy and safety of omalizumab in nasal polyposis: 2 randomized phase 3 trials. J Allergy Clin Immunol 2020;146(3):595-605.

23) Dennis SK, Lam K, Luong A. A review of classification schemes for chronic rhinosinusitis with nasal polyposis endotypes. Laryngoscope Investig Otolaryngol 2016;1(5):130-4.

24) Tomassen P, Vandeplas G, Van Zele T, Cardell LO, Arebro J, Olze $\mathrm{H}$, et al. Inflammatory endotypes of chronic rhinosinusitis based on cluster analysis of biomarkers. J Allergy Clin Immunol 2016; 137(5):1449-56.e4.

25) Kim C, Han J, Wu T, Bachert C, Fokkens W, Hellings P, et al. Role of biologics in chronic rhinosinusitis with nasal polyposis: State of the art review. Otolaryngol Head Neck Surg 2021;164(1):57-66.

26) Gevaert P, Lang-Loidolt D, Lackner A, Stammberger H, Staudinger H, Van Zele T, et al. Nasal IL-5 levels determine the response to anti-IL-5 treatment in patients with nasal polyps. J Allergy Clin Immunol 2006;118(5):1133-41.

27) Gevaert P, Van Bruaene N, Cattaert T, Van Steen K, Van Zele T, Acke F, et al. Mepolizumab, a humanized anti-IL-5 mAb, as a treatment option for severe nasal polyposis. J Allergy Clin Immunol 2011;128(5):989-95.e1-8.

28) Bachert C, Sousa AR, Lund VJ, Scadding GK, Gevaert P, Nasser S, et al. Reduced need for surgery in severe nasal polyposis with mepolizumab: Randomized trial. J Allergy Clin Immunol 2017; 140(4):1024-31.e14.

29) Han JK, Bachert C, Fokkens W, Desrosiers M, Wagenmann M, Lee SE, et al. Mepolizumab for chronic rhinosinusitis with nasal polyps (SYNAPSE): A randomised, double-blind, placebo-controlled, phase 3 trial. Lancet Respir Med 2021;9(10):1141-53.

30) Bakhshaee M, Fereidouni M, Nourollahian M, Movahed R. The presence of fungal-specific IgE in serum and sinonasal tissue among patients with sinonasal polyposis. Eur Arch Otorhinolaryngol 2014;271(11):2871-5.

31) Kariyawasam HH, James LK, Gane SB. Dupilumab: Clinical efficacy of blocking IL-4/IL-13 signalling in chronic rhinosinusitis with nasal polyps. Drug Des Devel Ther 2020;14:1757-69.

32) Bachert C, Zhang L, Gevaert P. Current and future treatment options for adult chronic rhinosinusitis: Focus on nasal polyposis. J Allergy Clin Immunol 2015;136(6):1431-40.

33) Bachert C, Mannent L, Naclerio RM, Mullol J, Ferguson BJ, Gevaert P, et al. Effect of subcutaneous dupilumab on nasal polyp burden in patients with chronic sinusitis and nasal polyposis: A randomized clinical trial. JAMA 2016;315(5):469-79.

34) Bachert C, Han JK, Desrosiers M, Hellings PW, Amin N, Lee SE, et al. Efficacy and safety of dupilumab in patients with severe chronic rhinosinusitis with nasal polyps (LIBERTY NP SINUS-24 and LIBERTY NP SINUS-52): Results from two multicentre, randomised, double-blind, placebo-controlled, parallel-group phase 3 trials. Lancet 2019;394(10209):1638-50.

35) Hellings PW, Verhoeven E, Fokkens WJ. State-of-the-art overview on biological treatment for CRSwNP. Rhinology 2021;59(2):151-63.

36) Nagarkar DR, Poposki JA, Tan BK, Comeau MR, Peters AT, Hulse $\mathrm{KE}$, et al. Thymic stromal lymphopoietin activity is increased in nasal polyps of patients with chronic rhinosinusitis. J Allergy Clin Immunol 2013;132(3):593-600.e12.

37) Wang WW, Lu DM, Zheng M, Zhang JG, Zhang B. TSLP regulates eotaxin-1 production by nasal epithelial cells from patients with eosinophilic CRSwNP. Rhinology 2018;56(4):370-7.

38) Liu T, Zhao F, Xie C, Liu AM, Li TL, Chen X, et al. Role of thymic stromal lymphopoietin in the pathogenesis of nasal polyposis. Am J Med Sci 2011;341(1):40-7.

39) Corren J, Parnes JR, Wang L, Mo M, Roseti SL, Griffiths JM, et al. Tezepelumab in adults with uncontrolled asthma. $\mathrm{N}$ Engl J Med 2017;377(10):936-46.

40) Kim DK, Jin HR, Eun KM, Mo JH, Cho SH, Oh S, et al. The role of interleukin-33 in chronic rhinosinusitis. Thorax 2017;72(7):63545.

41) Song W, Wang C, Zhou J, Pan S, Lin S. IL-33 expression in chronic rhinosinusitis with nasal polyps and its relationship with clinical severity. ORL J Otorhinolaryngol Relat Spec 2017;79(6):323-30.

42) Luo X, Li C, Wang Y, Yang G, Xu Y, Li G, et al. Interleukin-33 promotes Th2/Th17 response in eosinophilic and non-eosinophilic nasal polyps. ORL J Otorhinolaryngol Relat Spec 2020;82(1):34-9.

43) Fokkens WJ, Lund VJ, Hopkins C, Hellings PW, Kern R, Reitsma S, et al. Executive summary of EPOS 2020 including integrated care pathways. Rhinology 2020;58(2):82-111.

44) Castro M, Corren J, Pavord ID, Maspero J, Wenzel S, Rabe KF, et al. Dupilumab efficacy and safety in moderate-to-severe uncontrolled asthma. N Engl J Med 2018;378(26):2486-96.

45) Farne HA, Wilson A, Powell C, Bax L, Milan SJ. Anti-IL5 therapies for asthma. Cochrane Database Syst Rev 2017;(9):CD010834.

46) Rabe KF, Nair P, Brusselle G, Maspero JF, Castro M, Sher L, et al. Efficacy and safety of dupilumab in glucocorticoid-dependent severe asthma. N Engl J Med 2018;378(26):2475-85.

47) Bidder T, Sahota J, Rennie C, Lund VJ, Robinson DS, Kariyawasam HH. Omalizumab treats chronic rhinosinusitis with nasal polyps and asthma together-a real life study. Rhinology 2018;56(1):42-5. 
Korean J Otorhinolaryngol-Head Neck Surg I 2021;64(10):693-702

\section{정답 및 해설}

답 (3)

해설 보청기에 의한 외이의 만성 염증 상태로 지속적인 보청기 사용이 힘든 중등도의 난청에서는 중이이식형 보청기가 적당한 치료일 수 있다.

참고 문헌: Flint P, Haughey B, Lund V, Robbins K, Thomas JR, Lesperance M, et al. Cummings otolaryngology head and neck surgery. 6th ed. Philadelphia: Elsevier;2015. p.2411-21. 